University of Louisville

ThinkIR: The University of Louisville's Institutional Repository

Faculty Scholarship

$7-2020$

\title{
Real Talk: Librarian Perceptions of the Professional Conversation on Information Literacy Assessment
}

Amber Willenborg

University of Louisville, amber.willenborg@louisville.edu

Robert Detmering

University of Louisville, robert.detmering@louisville.edu

Samantha McClellan

California State University, Sacramento, s.mcclellan@csus.edu

Follow this and additional works at: https://ir.library.louisville.edu/faculty

Part of the Information Literacy Commons

Original Publication Information

portal: Libraries and the Academy, Vol. 20, No. 3 (July 2020), pp. 533-551

ThinkIR Citation

Willenborg, Amber; Detmering, Robert; and McClellan, Samantha, "Real Talk: Librarian Perceptions of the Professional Conversation on Information Literacy Assessment" (2020). Faculty Scholarship. 466.

https://ir.library.louisville.edu/faculty/466

This Article is brought to you for free and open access by ThinkIR: The University of Louisville's Institutional Repository. It has been accepted for inclusion in Faculty Scholarship by an authorized administrator of ThinkIR: The University of Louisville's Institutional Repository. For more information, please contact thinkir@louisville.edu. 


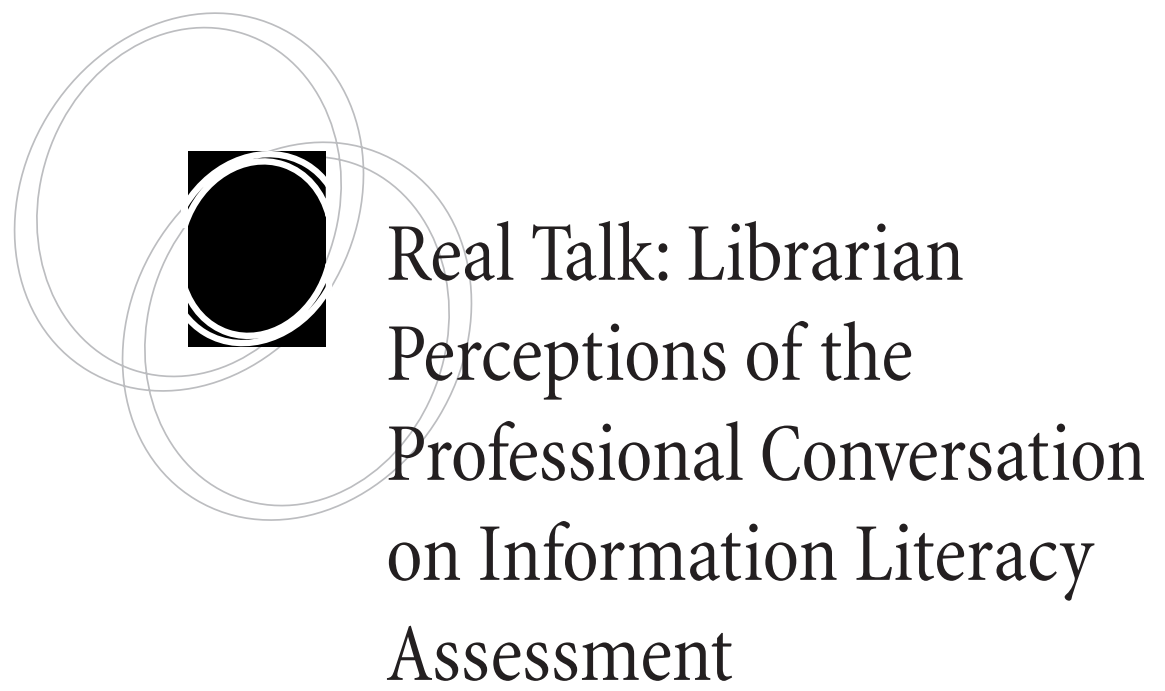

\section{Amber Willenborg, Robert Detmering, and Samantha McClellan}

abstract: This qualitative study investigates how academic librarians perceive the professional conversation about information literacy assessment, focusing on their characterization of the discourse and the benefits of and barriers to their participation. Findings from phenomenological interviews indicate that librarians view the conversation as valuable and inspiring, but also divisive and inapplicable to many libraries. While they find value in sharing ideas and engaging in a community of practice, they may face such barriers as feelings of inadequacy and insufficient resources. The authors provide recommendations to help librarians, administrators, and conference planners foster more inclusive and productive engagement in the professional conversation on information literacy assessment.

\section{Introduction}

$\mathrm{P}$ erusing the program for a conference, scanning the table of contents for a new issue of a journal, or reading through a spirited exchange on social media, one quickly recognizes that information literacy (IL) assessment remains a key topic in the professional conversation among instruction librarians. This is not surprising, given the now-longstanding consensus in the literature that assessment is essential for documenting the library's impact on student learning and communicating the value of IL programs to stakeholders. ${ }^{1}$ Moreover, several recent studies suggest that instruction librarians do not simply talk the talk but also embrace assessment as a genuine profes-

portal: Libraries and the Academy, Vol. 20, No. 3 (2020), pp. 533-551.

Copyright (c) 2020 by Johns Hopkins University Press, Baltimore, MD 21218. 
sional obligation and utilize a variety of methods to measure and document student learning. ${ }^{2}$ On the other hand, despite the generally widespread acceptance of assessment as a fundamental aspect of IL instruction, many librarians receive little, if any, formal training in assessment and may lack the necessary theoretical knowledge and practical

... instruction librarians do not simply talk the talk but also embrace assessment as a genuine professional obligation and utilize a variety of methods to measure and document student learning. skills to conduct it successfully. ${ }^{3}$ As a result, many instruction librarians must rely on conferences, webinars, journal articles, e-mail lists, and other interactions with the professional community to develop their skills.

The ongoing professional conversation surrounding assessment is crucial for the advancement of knowledge in this area, especially for librarians with less experience. Yet, we have a limited

understanding of how members of the profession perceive the conversation, what they learn or gain from it, and what motivates or impedes their participation. Library administrators, information literacy coordinators, conference planners, and journal editors, among others, can benefit from an investigation into how librarians experience and engage with the professional dialogue about assessment. Such is the purpose of the present study, which draws on qualitative data from semi-structured interviews to explore the following research questions:

- How do librarians characterize the professional conversation surrounding information literacy assessment?

- What do they learn or gain through participation in the professional conversation about information literacy assessment?

- What factors might impede or hinder librarians' participation in the professional conversation regarding information literacy assessment?

By looking closely at librarians' perceptions of the professional conversation on assessment, the authors intend to help interested parties foster more active participation in this discourse as well as enhance the appeal and quality of professional development offerings.

\section{Literature Review}

This study employs the broad term professional conversation to refer to any assessmentrelated dialogue or interaction within the larger professional community of instruction librarians. This includes, but is not limited to, conferences and other professional development programming, journal and news publications, and postings on e-mail lists and social media. The most relevant literature for this research focuses on professional development for librarians, along with the concept of communities of practice, groups of practitioners who interact with one another to learn to do their work better, as applied to librarianship. According to Robert Flatley and Michael Weber, academic librarians have "both a mandate and an expectation" to maintain current knowledge of the field 
and engage in professional development through conference attendance, publication, and other activities. ${ }^{4}$ Numerous scholars concur that, beyond the initial master of library science (MLS) degree, librarians require professional development and continuing education to keep their skills relevant and useful in light of technological and educational change. ${ }^{5}$ As noted earlier, the need for instruction librarians to improve their assessment skills has been clearly established in the literature, reflecting the growing emphasis on accountability in higher education. The perceived nature and impact of the professional conversation on assessment, as examined in this study, may have implications for the librarians who participate in this necessary professional development work.

While none focus specifically on assessment, several researchers have identified factors that influence academic librarians' level of participation in professional development. As a whole, this body of literature indicates that a variety of personal, organizational, and career motivations drive engagement with professional development activities. ${ }^{6}$ Personal motivations refer to the individual librarian's need to maintain or enhance job skills and abilities; organizational motivations refer to administrative and institutional support for professional development; and career motivations refer to the desire to participate in, contribute to, or gain recognition from the wider library profession. Research shows that organizational culture, specifically the extent to which an organization encourages and provides

... organizational culture, specifically the extent to which an organization encourages and provides funding for professional development, plays a particularly significant role in motivating librarians to participate. funding for professional development, plays a particularly significant role in motivating librarians to participate. ${ }^{7}$ Conversely, librarians consistently cite lack of funding and shortage of time as the primary barriers to taking part. $^{8}$ Adopting a similar approach to this prior research, the present study seeks to identify the motivations and barriers that affect librarians' involvement in the professional conversation on IL assessment.

Researchers have also investigated librarians' perspectives on the value or impact of professional development activities. For example, the literature highlights a number of benefits to conference attendance, such as networking, socializing, and sharing ideas with other librarians and scholars; being inspired professionally and intellectually; learning about disciplinary research trends; and hearing about new resources. ${ }^{9}$ Beyond conferences, others have noted the importance of joining and participating in professional organizations to build community, benefit from networking opportunities, and develop leadership skills or other competencies through mentoring relationships. ${ }^{10}$ Additionally, academic librarians point to e-mail list communications and journal publications as especially helpful for developing their knowledge and abilities. ${ }^{11}$ All this research suggests that engagement with the larger community of librarians via conferences, email lists, mentoring, and other activities contributes much to the perceived value of professional development.

The professional conversation among librarians therefore reflects an ongoing and multifaceted social process akin to a community of practice. As described by Etienne 
Wenger, communities of practice conceptualize learning as "a fundamentally social phenomenon," where fellow learners formulate meaning and identity through their interactions within a field or context. ${ }^{12}$ This idea is not new to academic librarianship and has been used to explain how lifelong learning occurs in the profession as librarians interact with one another to increase their knowledge over time, predominantly in informal settings. ${ }^{13}$ Indeed, the library literature features multiple examples of both in-person and online communities of practice, including educational programs, research collaborations, mentoring groups, and journal clubs. ${ }^{14}$ Discussing not only communities of practice but also other forms of professional training, Ramirose Ilene Attebury points to regular "social interaction" as one of the key elements of "meaningful and transformational professional development" for librarians. ${ }^{15}$ Two goals of the present study are to provide insight into how librarians perceive social interaction across the profession in relation to IL assessment (that is, the professional conversation) and to consider how librarians and library organizations might facilitate more meaningful, inclusive discourse in this expansive community of practice.

\section{Methods}

The purpose of this qualitative study is to investigate academic librarians' perceptions of the professional conversation surrounding IL assessment, focusing on how they characterize the conversation, what they gain or learn through participation, and what factors impede their participation. As in their previous study, ${ }_{1}^{16}$ the authors used a phenomenological approach which, according to Rick Fought, "focuses on revealing meaning and understanding the essence of a shared experience and works very well with phenomena that do not lend themselves to easy quantification." 17 As this study highlights common experiences among instruction librarians and the meaning they make from those experiences, a phenomenological research method is appropriate. ${ }^{18}$

Twenty-six participants were recruited in person and through librarian-focused e-mail lists and social media outlets between April and May 2017 to participate in an Institutional Review Board-approved study on the affective dimensions of IL assessment. All participants were full-time academic librarians with a master of library science degree and job responsibilities in IL instruction and assessment. The authors conducted interviews in person $(n=2)$ and over the phone $(n=24)$ with 23 female and 3 male participants ranging in age from 28 to $62($ mean $=40.32$; standard deviation $=11.49)$ from locations across the United States. Participants' length of employment ranged from six months to 30 years (mean $=11.2$ years), and they were employed by associate's colleges $(n=3)$, baccalaureate colleges $(n=1)$, master's universities or colleges $(n=6)$, doctoral universities $(n=14)$, and "other" institution types $(n=2)$, defined as a four-year comprehensive university and a tri-institutional academic library.

The authors used a semi-structured interview protocol (see the Appendix) to gain a deeper and more nuanced understanding of participants' experiences with IL assessment within four contexts: personal; within their own library; within the library profession; and within higher education. ${ }^{19}$ The authors' previous study addressed the personal and institutional contexts and focused on the qualitative experience of IL assessment work. ${ }^{20}$ The current study addresses librarians' experiences in the context of the library profession 
but turns the focus away from the day-to-day work of information literacy assessment and toward the larger professional conversation on that topic. To avoid influencing their responses, the term professional conversation was not defined for participants; rather, the authors' understanding of the professional conversation evolved through the analysis of participant responses.

Interviews ranged from 30 minutes to one hour and were recorded, transcribed, and analyzed for themes related to the research questions. The authors individually coded transcripts, then worked collaboratively to sort relevant quotations into thematic categories to find patterns among responses. Respondents are identified with pseudonyms to maintain anonymity.

\section{Results}

\section{Characterizing the Professional Conversation}

The first research question explored librarians' characterization of the professional conversation on IL assessment. Many respondents described the conversation using affective words, such as overwhelming, frustrating, confused, and hopeful. These feelings and others were conveyed in respondents' negative and positive characterizations of the conversation. Interestingly, librarians did not simply divide into camps of those describing

... many respondents provided both negative and positive characterizations of the professional conversation on IL assessment. the conversation negatively and those depicting it positively; rather, many respondents provided both negative and positive characterizations of the professional conversation on IL assessment.

\section{Negative Characterizations}

Several respondents described the professional conversation as divisive. DeAnna stated, "I think it has some tension in it. There definitely are voices on certain Listservs and conversations that go back and forth, and sometimes I wonder, what is this person's job that they can write and e-mail that long in the middle of the workday, like what are they doing?" Haley expanded on this idea of conflict within the conversation, saying, "I think there are some challenges that go along with it because it can seem very personal to people. I think it can be challenging in a personal way because, in some ways, it reflects on people's personalities and personal practices."

Similarly, many respondents noticed a clear divide between those who actively participated in the conversation and those who did not. DeAnna characterized the conversation as "somewhat spotty and dominated by certain voices," while Kasey discussed two types of participants: "I think there's people that have a lot of expertise and are very invested, and those conversations are professional and civil and cordial. But then I don't see a lot of pushback. But, I do hear some people actively disengage." Rachel noticed this same trend, stating, "If you reach out and really look, you can get into some really good conversations and find good information. But I think there's a lot who just aren't interested." 
The lack of interest and engagement among some librarians was one source of frustration among respondents who found the conversation insufficient. Mike remarked that the conversation "doesn't happen in enough places with enough librarians." Even where it occurs, some librarians, like Vanessa, felt that it moves forward too slowly:

I get a little annoyed when I do sense pushback occasionally, like why do we need to be doing [assessment]? And that annoys me, because that's not even part of the discussion to me anymore. It's more of, well, we need to get into the nitty-gritty details of how we're doing it, and I'm done talking about whether or not it's something we should do.

Sydney expressed concern that "some of the same themes seem to be coming up in conversation over and over again across, like, decades." Alexis agreed with this perception of being stuck: "[The conversation] is circuitous. I mean that ultimately I get it, we need to discuss it, but we discuss it a lot, and it doesn't get us anywhere."

While some librarians feel that the library profession needs to move forward faster when talking about IL assessment, others believe that librarianship needs to pull back from its emphasis on assessment to focus on other issues. Elyse asked, "Why can't we just let this go? I mean why can't we look at something else?" She characterized the focus on assessment in the professional conversation as "overblown and a distraction from some bigger issues the profession has." Sydney agreed that the discussion focuses on the wrong things; she describes it as "perverted" and goes on to explain, "I think it's getting, you could also say disoriented or confused. I think that folks are, in some cases, focusing on the wrong things."

One final negative characterization of the assessment conversation was that it does not apply to a wide audience of professionals. Becca summed this up, saying,

Everybody's all about assessment, I mean, with good reason, so that's great, but I think it comes down to everyone's having these conversations, but nobody's got any real practical "this is how it works" kind of situation, because that's — everybody's so unique, it's hard to translate from one situation to another. What works for you may not work for us.

This sentiment was echoed by several respondents, including Alexis: "I feel like a lot of the discussion professionally tends to be we go and we talk about it so we can come back and say we talked about assessment at this conference. But it doesn't change the way we do anything."

\section{Positive Characterizations}

Respondents also shared positive depictions of the professional conversation. Despite the negative description of the conversation as slow moving, some respondents saw it growing and moving in beneficial directions. Wes stated that the professional discourse has "gotten stronger and stronger over the years." Madison believes the conversation is "abuzz," while Haley sees it as "developing," and Trista stated that she feels positive about the "continuing and growing conversation."

Several respondents characterized the changing direction of the professional conversation as a way for librarians to mirror what is happening in higher education and to prove value. Courtney described the discourse as "very positive" and believes that this conversation in libraries "echoes a lot of what is happening in higher ed in general." 
Lindsay also sees the conversation within the library profession reflecting that in higher education: "I feel like there's definitely been kind of a big push for assessment, and I think that's in part because everybody has been trying to find ways to make sure that libraries remain relevant and part of the academic conversation."

Perhaps the most recurrent positive characterization of the conversation was that it serves as a community of practice for professionals to share ideas. Cassandra stated, "I think there's a lot of people who' re doing great stuff, and they're sharing it, which is totally awesome." Trista described the benefits of the assessment conference sessions she had recently attended:

It was really interesting to see the different tools that folks were using in different types of libraries and across different levels of instruction. You know, some people have fantastic places to store their data, others are using the spreadsheet method, and just having a mix of information available to talk about and be proud of, I think, is just really great.

This theme of the professional conversation as a community of practice carried over into responses for the second research question.

\section{What Librarians Gain through Participation}

Librarians also noted several benefits of involvement in the professional conversation surrounding IL assessment. The second research question explored what librarians learn or gain through participation in the discourse surrounding assessment. Responses fell into two categories: practical benefits, such as concrete ideas, direction, and professional advancement, and less tangible, affective benefits, such as inspiration and encouragement.

\section{Practical Benefits}

Many respondents described gaining ideas for their own IL assessment work through participation in the professional conversation. Sydney said, "When I hear things in the professional conversation about assessment and I think, oh, I really don't like the way they did that ... Or if I see something that looks interesting, I think, oh, I want to replicate what they did." Vanessa agreed, stating, "I think having practical versions of how people are using assessment kind of gives me ideas about how to refine my own." Similarly, respondents described how involvement in the professional conversation gave them direction and priorities for their own efforts. DeAnna stated that the conversation "is definitely helping frame what I introduce and what I prioritize in our professional conversations at a local level," and Caelynn described how the conversation "helps direct the kind of things I look at pursuing next." In addition to ideas and direction, some respondents mentioned the benefit of simply knowing what other libraries do in comparison to their own. Rozlyn believes her involvement in the discourse "just informs me whether or not what I'm doing is new and innovative." For these librarians, the professional conversation serves as a community of practice for continued growth in IL assessment.

In addition to ideas, direction, and awareness, respondents described the practical benefit of involvement in the conversation as a tool for professional advancement. Erica said, "I think if you do [assessment], then you can talk about it on the Listservs, you can 
present on it at conferences, which we've done, and that impacts the profession." Mike described professional advancement within his own institution and elsewhere, stating, "I look at [my engagement with the professional conversation] as part of the identity question that you asked earlier, but part of it is also based on promotion, whether it's my promotion here to faculty status or my promotion to, say, a director's position somewhere." Participation in the conversation allows these librarians to market themselves

Participation in the conversation allows these librarians to market themselves as knowledgeable in assessment, enabling them to move forward in their careers. as knowledgeable in assessment, enabling them to move forward in their careers.

A final practical benefit for librarians participating in the professional conversation on IL assessment was that they gained the ability to speak the language of assessment with teaching faculty and others in higher education. Courtney acknowledged that "all of higher education is interested

about assessment now" and that other disciplines "get the same kind of conversations about assessment as we do in our disciplines." Joelle believes that her involvement in the conversation within libraries "help[s] me have more intellectual conversations with faculty about student learning." These librarians feel equipped to participate in larger assessment conversations taking place in higher education due to their participation in the discourse in libraries.

\section{Affective Benefits}

Aside from the practical benefits of involvement in the conversation, respondents also described less tangible benefits they gain from participation. Sydney stated, "I think [the conversation] inspires me. I think it makes me feel that what I'm doing is relevant and that it matters because nobody would argue about it if nobody cared." Similarly, Mike believes the conversation "helps me to see the value other people place on [assessment]," while Erica is "encouraged to try different techniques that I might not have otherwise." Haley described the struggles she faces and the significance of a strong community of practice:

We recognize that other people have had to go through these difficult changes and they're on the other side or they're in the midst of it, so we sort of take comfort in that. Like, oh, they've done this, so I can do this, too. And that's kind of where I am with assessment. I'm kind of in the point where I'm like, OK, I can see ways of possibly going forward, but I also see, from the professional conversation, that other people are struggling with this, other people have struggled and are on the other side, this is something I can do.

These librarians feel a sense of community within the professional conversation and find inspiration and encouragement through participation.

\section{Factors Hindering Participation}

Although participation in the professional conversation has many benefits for instruction librarians, barriers hinder their participation. The third and final research question 
examined the factors influencing librarians' nonparticipation in the professional conversation. These challenges fell into two categories: personal barriers related to feelings of inadequacy and contextual obstacles relating to an individual librarian's institution or professional situation.

\section{Personal Barriers}

A recurrent barrier to participation in the assessment conversation was librarians' feelings of inadequacy in some aspect of their professional identity. Lindsay, a relatively new librarian, said, "In my job, I do quite a lot of assessment, but I've only been there for about 10 months, so I feel like I have a lot more experience to gain before I can be a real key player in the conversation." Although Bibiana has done assessment for some time, she never received formal training and thus feels uncomfortable actively participating in the conversation: "If you publish something, you want to feel kind of like an expert in it, although I never really felt like an expert in it. I think assessment is one of those areas where it's just like, do I really know enough to share?" DeAnna has some experience on her campus but believes her expertise is inadequate in the larger conversation happening in libraries: "I' $m$ doing it on my campus, and it seems acceptable, but I don't know if it would be accepted in the broader field of librarianship." These librarians feel that expertise on assessment is a prerequisite for participation in the professional conversation; because they lack that experience, they are not qualified to participate.

Interestingly, these feelings of inadequacy were especially strong regarding conversations on social media. Haley discussed her aversion to the fast-paced exchange on Twitter:

I think, for me, the challenges are just about my own sense of authority. Like do I have a right to have a voice in this, do I know enough to have a voice in this? I'm somebody who's like a lurker on Twitter, although I have even stopped lurking ... I just don't feel comfortable in my own self enough to kind of give you my spot judgment or, like, my hot takes about things in the world or things in assessment.

Similarly, Joelle stated:

A challenge for me is communicating through social media. I'm not comfortable with media backlashing ... I feel comfortable, you know, in the committee work that I do talking about assessment, you know, on my campus, writing about it, publishing about it, but when it comes to social media, just throwing something out, that's a challenge for me, and so I don't do it very often.

Conveying expertise on social media, then, can be challenging even for those who feel confident participating in assessment conversations elsewhere.

\section{Contextual Obstacles}

Besides personal feelings of inadequacy, many librarians discussed the contextual barriers to participation in the professional conversation. Respondents discussed lacking the resources to become actively involved. DeAnna cannot find the time: "I think that, in some ways, it is very theoretical, and that is not necessarily how I spend the majority of my time-thinking about my profession ... And I don't have a large amount of 
time to be doing professional reading." For Desiree, the challenge is a lack of money for professional development: "Especially being at a community college the last six years as opposed to a university, the challenges are resources. We don't have enough funding, for example, to send us every year to ACRL [the Association of College and Research Libraries annual conference]. And I think that's where a lot of the dynamic conversations are happening." Caelynn also works at a small institution that

always tends to be so far behind. I enjoy listening to the conversation. And I provide input when and where I can, but I always feel like I'm a few steps behind, especially the larger universities or the schools with lots of instruction librarians ... It's hard to force yourself to keep working on it when you know that you're light-years behind what some other people have been able to set up.

While these librarians might feel personally motivated to take part in the conversation, contextual barriers render them unable to participate.

Facing these types of contextual obstacles often leads librarians to feel that the professional conversation simply does not apply to their situation and thus involvement is not worth the effort. Alexis explained, "You go to a full-day preconference, and you go back and say, yes, I learned a lot about assessment, none of which I can apply." Becca is also frustrated by the irrelevance of the conversation to her particular context: "My thoughts usually orient around how could this work for us and could this scale down or scale up ... how is it applicable to us? Because so many times it's all theoretical, or all just pie-in-the-sky stuff, it's not really useful to anyone in particular." Because of the lack of applicability, Becca tends to distance herself from the conversation: "I try to avoid it at all costs. I don't want to have anything to do with it. It hurts my brain. So, I just try to ignore it unless there's some real, tangible, practical, like, can I make this work in my own situation." For these librarians, there is little useful to learn through the conversation, and thus their participation is pointless.

\section{Discussion and Recommendations}

The purpose of this study was to examine academic instruction librarians' experiences with the professional conversation surrounding information literacy assessment. Like the authors' previous research, ${ }^{21}$ this study examines the centrality of information literacy assessment within the library profession by delineating the affective dimension of assessment practice. This study contributes to the literature on professional development for librarians by identifying factors that influence participation in the professional conversation, and it adds to library-focused research on communities of practice. Respondents identified several benefits to engaging in the conversation, echoing the importance of shared experience and social learning through a community of practice as described by Wenger. ${ }^{22}$ In addition to benefits, respondents discussed impediments to participation and often provided conflicting positive and negative characterizations of the conversation. This tension is consistent with Wenger's description of communities of practice: they arise from joint enterprise, mutual engagement, and shared repertoire, but homogeneity is not a requirement, and "peace, happiness, and harmony are ... not necessary properties of a community of practice." 23 
This study indicates a number of challenges to participation that can inhibit a sense of community and professional growth. While the findings echo much of the previous research on barriers to engagement, specifically time, funding, and lack of organizational support, ${ }^{24}$ this study also finds that personal obstacles, such as feelings of inadequacy, hinder participation. Described by respondents as a lack of formal training and therefore inadequate expertise that hold them back from participating in the discourse, these reactions can be viewed as an instance of imposter syndrome as defined by Melanie Clark, Kimberly Vardeman, and Shelley Barba: "the feelings an individual experiences when he or she rightfully achieves a level of success but does not feel deserving of said success." ${ }^{25}$ Respondents described these fears of inadequacy as especially strong when the exchange takes place in an online setting, for example, e-mail lists and social media. They also specifically mentioned such issues as questioning their own expertise, certain individuals dominating conversations, and social media backlash. Building on Wenger's research on communities of practice, Khe Foon Hew identified seven determinants of successful online communities in supporting professional development: a willingness to share; high-quality content; diversity of views; ease and availability of necessary technology; relevant discussions; a respectful environment; and a rapid response to inquiries. ${ }^{26}$ Based on these determinants, the authors suggest that the responsibility for enhancing ...the responsibility for enhancing the online professional conversation on IL assessment lies both with individual librarians to share their unique perspectives as well as with forum moderators to cultivate productive discussions and promote respectful discourse. the online professional conversation on IL assessment lies both with individual librarians to share their unique perspectives as well as with forum moderators to cultivate productive discussions and promote respectful discourse.

In addition to striving for positive engagement in online communities, the authors suggest that individual librarians can overcome roadblocks to engagement in the professional conversation. One way to do this is to keep up with the literature of librarianship. Staying abreast of the literature may bolster confidence and erode feelings of imposter syndrome. It may also help librarians break free from what some respondents described as circuitous or narrow discussions on IL assessment by keeping them informed about current developments in the profession and giving them ideas for moving their own work forward.$^{27}$ Librarians with little time to devote to the literature can set up journal alerts for one or two key topics of interest and put a scheduled 30-minute event in their weekly calendar to read. Librarians can also reach out to colleagues with similar interests and create a network to share interesting articles within the group. Relatedly, another way to stay up-to-date is to engage with e-mail lists, particularly by asking questions or contributing answers, and then sharing the responses or archiving them in a public way to help facilitate individual and shared growth on best practices in IL assessment. The authors recommend that librarians find one e-mail list or forum with which they are comfortable to build confidence in asking questions and contributing knowledge. 
Seeking out context-specific forums, such as the Librarian Parlor for new librarians or e-mail lists specific to community college libraries, can also benefit librarians who feel that the conversation is inapplicable. Librarians can also create informal regional "unconferences" where participants drive the agenda. Such meetings could help those respondents who feel the conversation is redundant or not applicable to their context, while also addressing the issue of disengagement and disinterest by allowing librarians to decide what they want to learn. Lastly, the authors encourage librarians to feel confident in where they stand professionally. ${ }^{28}$ The authors' findings suggest that even those respondents with robust IL assessment programs can still learn from one another.

As the findings indicate, bolstering positive engagement in the professional conversation cannot be an individual endeavor. As affirmed by previous research, it largely relates to institutional support and how professional organizations facilitate their attendees' experience. ${ }^{29}$ At the institutional level, the authors provide the following recommendations for individuals to engage their colleagues in shared professional conversation: facilitate peer sharing opportunities; ask the library administration to pay for webinars; and find others involved or interested in assessment outside the library

... webinars can serve as

an affordable alternative to

conference attendance but still contribute new ideas and potentially connect librarians at similar institutions. on your campus. Peer sharing opportunities, such as half-day retreats for librarians at nearby institutions, have the potential to create a local community of practice with lower stakes than a national conference presentation. Additionally, webinars can serve as an affordable alternative to conference attendance but still contribute new ideas and potentially connect librarians at similar institutions. Seeking out others on campus who share a passion for engaging in discussions around assessment has the poten-

tial not only to positively impact participation but also to market library instruction services and to demonstrate to those on campus that the library's need to prove its value mirrors that of higher education. Lastly, the authors point to research indicating that a supportive organizational climate has a positive impact on academic librarians' professional development. ${ }^{30}$ Therefore, they recommend that library administrators encourage their librarians to share what they have learned at conferences and other professional conversation outlets, contributing to the feeling that their attendance and learning benefits the organization.

The library profession should also consider librarians' perceptions of the conversation to develop useful content and facilitate effective communication across professional channels. The authors' findings can help professional associations and committees develop a vibrant community that fosters, rather than inhibits, participation. Based on these findings, the authors suggest action items for professional organizations: offer smaller, low stakes mini-conferences; solicit proposals on assessment that talk about failures or the assessment process and how it has evolved over time; create context-specific conference tags such as new librarian, experienced librarian, or small institution to allow librarians to find more applicable presentations to attend; bring in new and underrepresented voices to talk about assessment; and identify ways to offset costs for participants. The authors suggest looking to smaller conferences that have made strides in this area, such as the 
Library Collective, a nonprofit organization dedicated to innovation and education for librarians. Corey Halaychik and Ashley Maynor describe how the Library Collective purposefully keeps attendee costs low to increase accessibility, provides detailed feedback on proposals regardless of acceptance, and makes conference comments public to demonstrate quality and continuous improvement. ${ }^{31}$ Conferences like this can address the lack of resources for professional development faced by some librarians while also providing transparency to participants.

The authors acknowledge some limitations within the present study. Namely, a majority of participants identified as white, heterosexual females. While this breakdown aligns with the demographics of the profession, ${ }^{32}$ it would be interesting to explore barriers to engagement with other demographic groups as the profession seeks to diversify. Another limitation is the homogeneity of institution types represented in the study. Twenty of the 26 participants came from masters- or doctoral-granting institutions. Librarians at community colleges may experience more fiscal or staffing barriers to attending the large conferences where many assessment conversations take place. Future research could explore engagement in the professional conversation in more depth with community colleges to identify recommendations for different institution types. Similarly, future research could look more granularly at length of employment, previous involvement with professional development activities, and other demographic or professional variables in tandem with responses to gain a deeper understanding of factors influencing engagement. Lastly, all three authors are instruction librarians with varying expertise in IL assessment and different involvement in the professional conversation surrounding it. Although the authors sought to maintain objectivity while interviewing respondents, their experiences with and engagement in the professional conversation may have inadvertently influenced their interview protocol and analysis of results.

This study provides an in-depth, qualitative portrait of academic instruction librarians' perspectives on the professional conversation surrounding information literacy assessment, delineating their characterizations of the discourse along with benefits and barriers to participation. As previously indicated, there are interesting avenues for future research, such as examining the professional exchange on social media or investigating how imposter syndrome affects participation in the professional conversation. Additionally, it may be interesting to look at how characterizations of and engagement with the professional conversation are impacted when one or more of the recommendations has been applied. Studies like this may lead to greater understanding of how academic instruction librarians experience the professional conversation, which will serve to strengthen the sense of community they feel. Such studies may encourage professional organizations to respond by taking a more proactive approach to foster inclusive engagement in professional development offerings.

Amber Willenborg is the online learning and digital media librarian at the University of Louisville in Louisville, Kentucky; she may be reached by e-mail at: amber.willenborg@louisville.edu.

Robert Detmering is the information literacy coordinator at the University of Louisville in Louisville, Kentucky; he may be reached by e-mail at: robert.detmering@louisville.edu.

Samantha McClellan is the library instruction coordinator at California State University in Sacramento; she may be reached by e-mail at: s.mcclellan@csus.edu. 


\section{Appendix}

\section{Interview Guide}

\section{Professional Variables}

What type of librarian would you classify yourself as?

How long have you been employed as a librarian?

What did you major in as an undergraduate student?

Where did you obtain your undergraduate degree?

Where did you obtain your master of library science degree?

Are there any other degrees or training you have?

Do you have any specific training in assessment?

As a part of your job duties, what percentage would you assign to your responsibilities related to information literacy instruction?

How many classes do you teach in an academic year?

As a part of your job duties, how often do you interact with students? [1-10, 10 being high interaction]

As a part of your job duties, how often do you interact with faculty? [1-10, 10 being high interaction]

Which description is the best fit for your institution type? (doctoral university, master's university / college, baccalaureate college, associate's college, other-please describe.)

Is your institution public or private?

What is the size of your institution?

- 0-5,000 students

- 5,001-10,000 students

- 10,001-15,000 students

- 15,001-20,000 students

- 20,001-25,000 students

- 25,001-30,000 students

- 30,001-35,000 students

- 35,001-40,000 students

- More than 40,000 students

\section{Librarians and Assessment: Personal/General}

What do you think the role of assessment is in library instruction?

Do you do assessment for library instruction?

What kinds of assessment do you do for library instruction? 
Why do you do assessment for library instruction? (Personal practice, mandated by library or university administration, pressure from profession, combination, other?)

What do you think about doing assessment for library instruction?

How do you feel about doing assessment for library instruction?

Are there any challenges you have in doing assessment for library instruction?

How have you responded to these challenges?

How do these things we've been talking about affect how you perform your job responsibilities?

How do these things we've been talking about affect your professional identity?

\section{Librarians and Assessment: Calls from Library Administration}

How would you characterize the conversation about assessment at your library?

Are you required to assess library instruction as a part of your job duties by library administration?

Do you report the assessment data to anyone at your library? (Recommended, mandated, other?)

If yes, ask the following questions:

What do you think about reporting assessment data to library administration?

How do you feel about reporting assessment data to library administration?

Are there any challenges to reporting assessment data to library administration?

How have you responded to these challenges in reporting assessment data to library administration?

How do these things we've been talking about affect how you perform your job responsibilities?

How do these things we've been talking about affect your professional identity?

If no, ask the following questions:

What do you think about not reporting assessment data to library administration?

How do you feel about not reporting assessment data to library administration?

Are there challenges associated with not reporting assessment data to the library administration?

How have you responded to these challenges associated with not reporting assessment data to the library administration?

How do these things we've been talking about affect how you perform your job responsibilities?

How do these things we've been talking about affect your professional identity? 


\section{Librarians and Assessment: Calls from the Profession}

How would you characterize the professional conversation about assessment?

Do you see your library fitting into this professional conversation? How?

What do you think about the professional conversation surrounding assessment?

How do you feel about the professional conversation surrounding assessment?

What are any challenges you have about fitting into the professional conversation surrounding assessment?

How have you responded to the professional conversation surrounding assessment?

How do these things we've been talking about affect how you perform your job duties?

How do these things we've been talking about affect your professional identity?

\section{Librarians and Assessment: Call from Higher Education}

How would you characterize the conversation about assessment in higher education?

What are your thoughts on calls for accountability in higher education?

Do you see the library fitting into the call for accountability? How?

What do you think about the library fitting into the call for accountability?

How do you feel about the library fitting into the call for accountability?

What are challenges to fitting the library into the call for accountability?

How have you responded to calls from higher education to demonstrate the library's accountability?

How do these things we've been talking about affect how you perform your job duties?

How do these things we've been talking about affect your professional identity?

How have you or your library responded to calls for accountability at your institution?

Do you report your assessment data to anyone at the institution? (If not, is someone at your library reporting it to the institution?)

If yes, ask the following questions:

If so, do you know how the data are used by the institution?

What do you think about reporting assessment data to the institution?

How do you feel about reporting assessment data to the institution?

What are challenges associated with reporting assessment data to the institution?

How do these things we've been talking about affect how you perform your job duties?

How do these things we've been talking about affect your professional identity? 
If no, ask the following questions:

What do you think about not reporting assessment data to the institution?

How do you feel about not reporting assessment data to the institution?

What are challenges associated with not reporting assessment data to the institution?

How do these things we've been talking about affect how you perform your job duties?

How do these things we've been talking about affect your professional identity?

\section{Demographic Variables}

What is your age?

What is your sex?

How would you define your race or ethnicity?

How would you define your sexual orientation?

How would you define your relationship status?

\section{Notes}

1. Allison Erlinger, "Outcomes Assessment in Undergraduate Information Literacy: A Systematic Review," College \& Research Libraries 79, 4 (2018): 442-79, https:/ / crl.acrl.org/ index.php/crl/article/view/16600; Debra L. Gilchrist, "A Twenty Year Path: Learning about Assessment; Learning from Assessment," Communications in Information Literacy 3, 2 (2010): 70-79, https:/ / pdxscholar.library.pdx.edu/comminfolit/vol3/iss2/3/; Yvonne Nalani Meulemans, "Assessment City: The Past, Present, and Future State of Information Literacy Assessment," College \& Undergraduate Libraries 9, 2 (2002): 61-74, https:/ / doi. org/10.1300/J106v09n02_07; Megan Oakleaf, "Dangers and Opportunities: A Conceptual Map of Information Literacy Assessment Approaches," portal: Libraries and the Academy 8, 3 (2008): 233-53, https: / / muse.jhu.edu/article/240410.

2. Karen Brown and Kara J. Malenfant, "Academic Library Contributions to Student Success: Documented Practices from the Field," 2015, http:/ / www.ala.org/acrl/sites/ala.org.acrl/ files / content / issues / value/ contributions_report.pdf; Erlinger, "Outcomes Assessment in Undergraduate Information Literacy"; Devin Savage, Pattie Piotrowski, and Lisa Massengale, "Academic Librarians Engage with Assessment Methods and Tools," portal: Libraries and the Academy 17, 2 (2017): 403-17, https: / / muse.jhu.edu/article/ 653213.

3. Erlinger, "Outcomes Assessment in Undergraduate Information Literacy"; Lisa Janicke Hinchliffe and Megan Oakleaf, "Assessment Cycle or Circular File: Do Academic Librarians Use Information Literacy Assessment Data?" Proceedings of the Library Assessment Conference (Seattle, WA: Association of Research Libraries, 2008), 159-64, https: / / papers.ssrn.com/sol3 / papers.cfm?abstract_id=2597894; Karen Sobel and Cassidy R. Sugimoto, "Assessment of Learning during Library Instruction: Practices, Prevalence, and Preparation," Journal of Academic Librarianship 38, 4 (2012): 191-204, https: / / doi. org/10.1016/j.acalib.2012.04.004.

4. Robert K. Flatley and Michael A. Weber, "Perspectives on ... Professional Development Opportunities for New Academic Librarians," Journal of Academic Librarianship 30, 6 (2004): 488, https: / / doi.org/10.1016/j.acalib.2004.06.011.

5. Ramirose Ilene Attebury, "The Role of Administrators in Professional Development: Considerations for Facilitating Learning among Academic Librarians," Journal of Library 
Administration 58, 3 (2018): 407-33, https: / / doi.org/10.1080/01930826.2018.1468190; Rebecca Blakiston, "Building Knowledge, Skills, and Abilities: Continual Learning in the New Information Landscape," Journal of Library Administration 51, 7-8 (2011): 728-43, https: / / doi.org/10.1080/01930826.2011.601272; Maura Corcoran and Claire McGuinness, "Keeping Ahead of the Curve: Academic Librarians and Continuing Professional Development in Ireland," Library Management 35, 3 (2014): 175-98, https: / / www.emerald. com/insight/ content/ doi/10.1108/LM-06-2013-0048/full/html; Sylvia D. Hall-Ellis and Deborah S. Grealy, "The [Hubert and Stuart] Dreyfus Model of Skill Acquisition: A Career Development Framework for Succession Planning and Management in Academic Libraries," College \& Research Libraries 74, 6 (2013): 587-603, https:/ / crl.acrl.org/index.php/ $\mathrm{crl} /$ article/view/16340.

6. Attebury, "The Role of Administrators in Professional Development"; Mary Cassner and Kate E. Adams, "Assessing the Professional Development Needs of Distance Librarians in Academic Libraries," Journal of Library Administration 45, 1-2 (2006): 81-99, https: / / doi. org/10.1300/J111v45n01_05; Corcoran and McGuinness, "Keeping Ahead of the Curve"; W. Michael Havener and Wilbur A. Stolt, "The Professional Development Activities of Academic Librarians: Does Institutional Support Make a Difference?" College \& Research Libraries 55, 1 (1994): 25-36, https:/ / crl.acrl.org/index.php/crl/article/view/14862/0; Kaetrena Davis Kendrick, Deborah Tritt, and Echo Leaver, "Link Up the Sticks: Access and Barriers to Professional Development for Small and Rural Academic Librarians," Codex 2, 3 (2013): 38-77, http:/ / journal.acrlla.org/index.php/codex/article/view/78; Duncan Smith and Robert Burgin, "The Motivations of Professional and Paraprofessional Librarians for Participating in Continuing Education Programs," Library and Information Science Research 13, 4 (1991): 405-29, https:/ / eric.ed.gov/ ?id=EJ443257.

7. Blakiston, "Building Knowledge, Skills, and Abilities"; Havener and Stolt, "The Professional Development Activities of Academic Librarians."

8. Attebury, "The Role of Administrators in Professional Development"; Cassner and Adams, "Assessing the Professional Development Needs of Distance Librarians in Academic Libraries"; Corcoran and McGuinness, "Keeping Ahead of the Curve."

9. Edward Bilodeau and Pamela Carson, "The Role of Communities of Practice in the Professional Education of Academic Librarians," Education for Information 31, 1-2 (2015): 2551, https: / / doi.org/10.3233/EFI-150949; Rachel Harrison, "Unique Benefits of Conference Attendance as a Method of Professional Development for LIS Professionals," Serials Librarian 59, 3-4 (2010): 263-70, https: / / doi.org/10.1080/0361526X.2010.489353; Lucy Eleonore Lyons, "The Dilemma for Academic Librarians with Collection Development Responsibilities: A Comparison of the Value of Attending Library Conferences versus Academic Conferences," Journal of Academic Librarianship 33, 2 (2007): 180-89, https:/ / doi.org/10.1016/j.acalib.2006.12.001; Robert Tomaszewski and Karen I. MacDonald, "Identifying Subject-Specific Conferences as Professional Development Opportunities for the Academic Librarian," Journal of Academic Librarianship 35, 6 (2009): 583-90, https: / / doi.org/10.1016/j.acalib.2009.08.006; Robert D. Vega and Ruth S. Connell, “Librarians' Attitudes toward Conferences: A Study," College \& Research Libraries 68, 6 (2007): 503-16, https: / / crl.acrl.org/index.php/crl/article/view/15900.

10. Jeanne R. Davidson and Cheryl A. Middleton, “Networking, Networking, Networking: The Role of Professional Association Memberships in Mentoring and Retention of Science Librarians," Science \& Technology Libraries 27, 1-2 (2006): 203-24, https:/ / doi.org/10.1300 / J122v27n01_14; Donald G. Frank, "Activity in Professional Associations: The Positive Difference in a Librarian's Career," Library Trends 46, 2 (1997): 307-19; Diane Zabel, "The Mentoring Role of Professional Associations," Journal of Business \& Finance Librarianship 13, 3 (2008): 349-61, https: / / doi.org/10.1080/08963560802183187.

11. Bilodeau and Carson, "The Role of Communities of Practice in the Professional Education of Academic Librarians"; Skye Hardesty and Tammy Sugarman, "Academic Librarians, Professional Literature, and New Technologies: A Survey," Journal of Academic Librarianship 33, 2 (2007): 196-205, https: / / doi.org/10.1016/j.acalib.2006.12.006. 
12. Etienne Wenger, Communities of Practice: Learning, Meaning, and Identity (Cambridge, U.K.: Cambridge University Press, 1998), 3.

13. Bilodeau and Carson, "The Role of Communities of Practice in the Professional Education of Academic Librarians."

14. Ramirose Ilene Attebury, "Adult Education Concepts in Library Professional Development Activities," New Library World 116, 5-6 (2015): 302-15, https: / / www.emerald.com/insight / content/doi/10.1108/NLW-08-2014-0100/full/html; Bilodeau and Carson, "The Role of Communities of Practice in the Professional Education of Academic Librarians"; Jong-Ae Kim, "Integrating Communities of Practice into Library Services," Collaborative Librarianship 7, 2 (2015): 47-55, https:/ / digitalcommons.du.edu/collaborativelibrarianship/vol7 / iss $2 / 2 /$.

15. Ramirose Ilene Attebury, "Professional Development: A Qualitative Study of High Impact Characteristics Affecting Meaningful and Transformational Learning," Journal of Academic Librarianship 43, 3 (2017): 240, https: / / doi.org/10.1016/j.acalib.2017.02.015.

16. Robert Detmering, Samantha McClellan, and Amber Willenborg, "A Seat at the Table: Information Literacy Assessment and Professional Legitimacy," College \& Research Libraries 80, 5 (2019): 720-37, https: / / doi.org/10.5860/ crl.80.5.720.

17. Rick L. Fought and Mitsunori Misawa, "Accepting the Challenge: What Academic Health Sciences Library Directors Do to Become Effective Leaders," Journal of the Medical Library Association 106, 2 (2018): 220, http://jmla.pitt.edu/ojs/jmla/article/view/350.

18. Irving Seidman, Interviewing as Qualitative Research: A Guide for Researchers in Education and the Social Sciences, 4th ed. (New York: Teachers College Press, 2013).

19. John Lofland, Lyn Lofland, David Snow, and Leon Anderson, Analyzing Social Settings: A Guide to Qualitative Observation and Analysis, 4th ed. (Belmont, CA: Wadsworth, 2006).

20. Detmering, McClellan, and Willenborg, "A Seat at the Table."

21. Ibid.

22. Wenger, Communities of Practice: Learning, Meaning, and Identity.

23. Ibid., 77.

24. Attebury, "The Role of Administrators in Professional Development"; Cassner and Adams, "Assessing the Professional Development Needs of Distance Librarians in Academic Libraries"; Corcoran and McGuinness, "Keeping Ahead of the Curve."

25. Melanie Clark, Kimberly Vardeman, and Shelley Barba, "Perceived Inadequacy: A Study of the Imposter Phenomenon among College and Research Librarians," College \& Research Libraries 75, 3 (2014): 255, https: / / doi.org/10.5860/ crl12-423.

26. Khe Foon Hew, "Determinants of Success for Online Communities: An Analysis of Three Communities in Terms of Members' Perceived Professional Development," Behaviour \& Information Technology 28, 5 (2009): 433-45, https: / / doi.org/10.1080 / 01449290802005995.

27. Hardesty and Sugarman, "Academic Librarians, Professional Literature, and New Technologies."

28. Clark, Vardeman, and Barba, "Perceived Inadequacy."

29. Blakiston, "Building Knowledge, Skills, and Abilities"; Havener and Stolt, "The Professional Development Activities of Academic Librarians."

30. Donna C. Chan and Ethel Auster, "Factors Contributing to the Professional Development of Reference Librarians," Library \& Information Science Research 25, 3 (2003): 265-86, https: / / doi.org/10.1016/S0740-8188(03)00030-6; Havener and Stolt, “The Professional Development Activities of Academic Librarians"; Hilde Terese Drivenes Johannessen, "The Need to Grow, Learn and Develop-How Does Management Affect Motivation for Professional Development?" LIBER Quarterly: The Journal of the Association of European Research Libraries 28, 1 (2018): 1-16, https: / / doi.org/10.18352/ lq.10238.

31. Corey Halaychik and Ashley Maynor, "What Collaboration Means to Me: How We Do and Don't Collaborate at the Library Collective," Collaborative Librarianship 10, 3 (2018): 152-55, https:/ / digitalcommons.du.edu/collaborativelibrarianship/vol10/iss3/2/.

32. Andrew A. Beveridge, Susan Weber, and Sydney Beveridge, "Librarians in the United States from 1880-2009," 2011, https:/ / blog.oup.com/2011/06/librarian-census/. 